\section{A Rare Case of Small}

\section{Bowel Undifferentiated}

Pleomorphic Sarcoma:

Imaging Findings on $\mathrm{CT}$

and Magnetic Resonance

\section{Enterography}

소장의 원발성 미분화성 다형성육종 증례 보고:
전산화단층촬영 및 $\mathrm{MR}$ 소장조영술에서의 영상 소견

Yeo Eun Han, MD ${ }^{1}$, Soo Young Chae, $\mathrm{MD}^{1}$, Jeong Hyeon Lee, $\mathrm{PhD}^{2}$, Beom Jin Park, $\mathrm{PhD}^{1}$, Deuk Jae Sung, $\mathrm{PhD}^{1}$, Na Yeon Han, $\mathrm{PhD}^{1}$, Ki Choon Sim, MD ${ }^{1}$, Min Ju Kim, $\mathrm{PhD}^{1 *}$ (D)

Departments of ${ }^{1}$ Radiology, ${ }^{2}$ Pathology, Korea University Anam Hospital, Korea University College of Medicine, Seoul, Korea

Gastrointestinal tract involvement in undifferentiated pleomorphic sarcoma (UPS) is extremely rare. To the authors' knowledge, only 21 cases of primary small bowel UPS have been reported in the literature available in English. Reported CT findings in primary small bowel UPS have been nonspecific, and MRI findings have been reported in only one case. The present article describes a case involving a 72-year-old male with histologically confirmed primary UPS arising from the ileum, focusing on both $\mathrm{CT}$ and magnetic resonance enterography findings. On CT, primary small bowel UPS was noted as a heterogeneously enhanced small bowel mass without obstruction. Magnetic resonance enterography revealed heterogeneous intermediate T1 and T2 signal intensity, with hemorrhagic or necrotic foci within the mass and heterogeneous enhancement. The differential diagnosis included malignant gastrointestinal tumor; however, the prognosis of UPS is worse, with higher incidences of extra-abdominal metastasis.

Index terms Malignant Fibrous Histiocytoma; Histiocytoma;

Pleomorphic Malignant Fibrous Histiocytoma; Small Intestine;

Tomography, X-Ray Computed; Magnetic Resonance Imaging
Received June 12, 2018

Revised July 19, 2018

Accepted July 29, 2018

${ }^{\star}$ Corresponding author

Min Ju Kim, PhD

Department of Radiology, Korea

University Anam Hospital, Korea University College of Medicine,

73 Inchon-ro, Seongbuk-gu,

Seoul 02841, Korea.

Tel 82-2-920-5578

Fax 82-2-929-3796

E-mail dr.minjukim@gmail.com

This is an Open Access article distributed under the terms of the Creative Commons Attribution Non-Commercial License (https://creativecommons.org/ licenses/by-nc/4.0) which permits unrestricted non-commercial use, distri-bution, and reproduction in any medium, provided the original work is properly cited.

\section{ORCID iDs}

Min Ju Kim (D)

https://

orcid.org/0000-0003-0979-9835

Yeo Eun Han (D)

https://

orcid.org/0000-0002-3922-9326 


\section{INTRODUCTION}

In the past, undifferentiated pleomorphic sarcoma (UPS) was often referred to as malignant fibrous histiocytoma, which is the pleomorphic variant of undifferentiated soft tissue sarcoma, a heterogeneous group exhibiting no identifiable line of differentiation of soft tissue sarcoma. UPS occurs primarily in older adults and may be found in any location, but most commonly in the lower extremities, followed by the retroperitoneum. Gastrointestinal (GI) tract involvement in UPS is extremely rare, with only 21 cases of primary UPS of the small bowel reported in the literature available in English. Among these 21 cases, 13 reports described CT findings, and only one described MRI findings in small bowel UPS.

We report a case of UPS arising in the proximal ileum, and emphasize on the use of small bowel cross-sectional imaging, and this is the first case of small bowel UPS describing both CT and MR enterography findings.

\section{CASE REPORT}

A 72-year-old man visited the authors' institution complaining of chest pain for 3 days. No other symptoms, such as abdominal pain or weight loss, were noted. He had past history of coronary arterial disease and diabetes mellitus. Transfemoral coronary angiography was performed and unstable angina was suspected for the cause of the chest pain. On the physical examination, the abdomen was soft and non-tender, and no mass was palpable. Laboratory investigations revealed severe anemia and elevated white blood cell count and C-reactive protein level (hemoglobin, $5.8 \mathrm{~g} / \mathrm{dL}$; C-reactive protein, $60.2 \mathrm{mg} / \mathrm{L}$; white blood cell

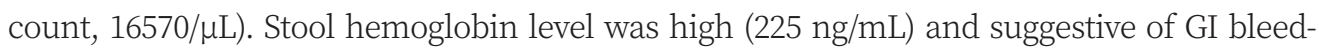
ing. Although emergency esophagogastroduodenoscopy and sigmoidoscopy were performed, there was no significant bleeding focus. Therefore, CT enterography was performed to exclude small bowel bleeding.

CT enterography (using oral contrast for adequate luminal distention) revealed a lobulated contoured polypoid intraluminal mass in the ileum measuring $6.8 \times 6.2 \times 3.8 \mathrm{~cm}$ (Fig. 1A). After intravenous contrast administration, the mass exhibited heterogeneous enhancement on the arterial and portal phases. There was no evidence of obstruction, and mucosal and submucosal layer involvement was suspected. There was no significant lymphadenopathy or metastatic lesions in the abdominopelvic cavity or retroperitoneum. Initial assessment based on CT enterography findings was GI stromal tumor (GIST). The differential diagnosis included lymphoma or primary ileal adenocarcinoma.

MR enterography was performed six days later, which revealed that the location of the mass changed, and the mass was now located in the lower mid abdomen (Fig. 1B-E). There was no local invasion or desmoplastic reaction by the mass. The mass exhibited heterogeneous, intermediate T1 (Fig. 1B) and T2 (Fig. 1C) signal intensity (SI) relative to muscle. The mass exhibited heterogeneous and persistent enhancement at 40 s, 70 s (Fig. 1D), 3, 4, and 5 min after contrast administration. Diffusion restriction was noted in the entire mass (Fig. 1E). On T2-weighted imaging, there were tiny, multifocal high SI foci in the mass, suggesting necrosis (Fig. 1C). In the dynamic study, the mass exhibited tiny, multifocal low SI areas with- 
out enhancement, also suggestive of necrosis or hemorrhagic spots (Fig. 1D). The final assessment was malignant tumor of the ileum, such as malignant GIST.

The patient underwent laparoscopic segmental resection of the ileum. The mass was located $30 \mathrm{~cm}$ above the terminal ileum and there was no adhesion. On gross examination, a 12.4

Fig. 1. Primary undifferentiated pleomorphic sarcoma of the small bowel in a 72-year-old male patient.

A. CT enterography revealing a mass $6.8 \mathrm{~cm}$ in size at the ileum, exhibiting endoluminal and exoluminal growth. On the portal phase, the mass exhibits heterogeneous enhancement (arrow).

B. On T1WI in MR enterography, the mass exhibited heterogeneous intermediate signal intensity (arrow).

C. On T2WI, the mass exhibited heterogeneous intermediate signal intensity with T2 hyperintense foci (arrow).

D. On T1WI (fat suppressed), $70 \mathrm{~s}$ after intravenous contrast administration, the mass exhibited heterogeneous enhancement with non-enhancing foci (arrow).

E. On the ADC map, the mass exhibited diffuse restriction with a low ADC value (arrow).

F. On gross examination, a $12.4 \times 7.9 \times 3.8 \mathrm{~cm}$ exophytic soft mass (arrow) was identified in the small intestinal wall. Microscopic examination (hematoxylin and eosin, $\times 100$ ) revealed solid sheets of malignant tumor cells, which are mixture of spindle cells with vague fascicular pattern, pleomorphic cells, and a considerable number of bizarre multinucleated tumor giant cells.

$A D C=$ apparent diffusion coefficient, $W I=$ weighted imaging
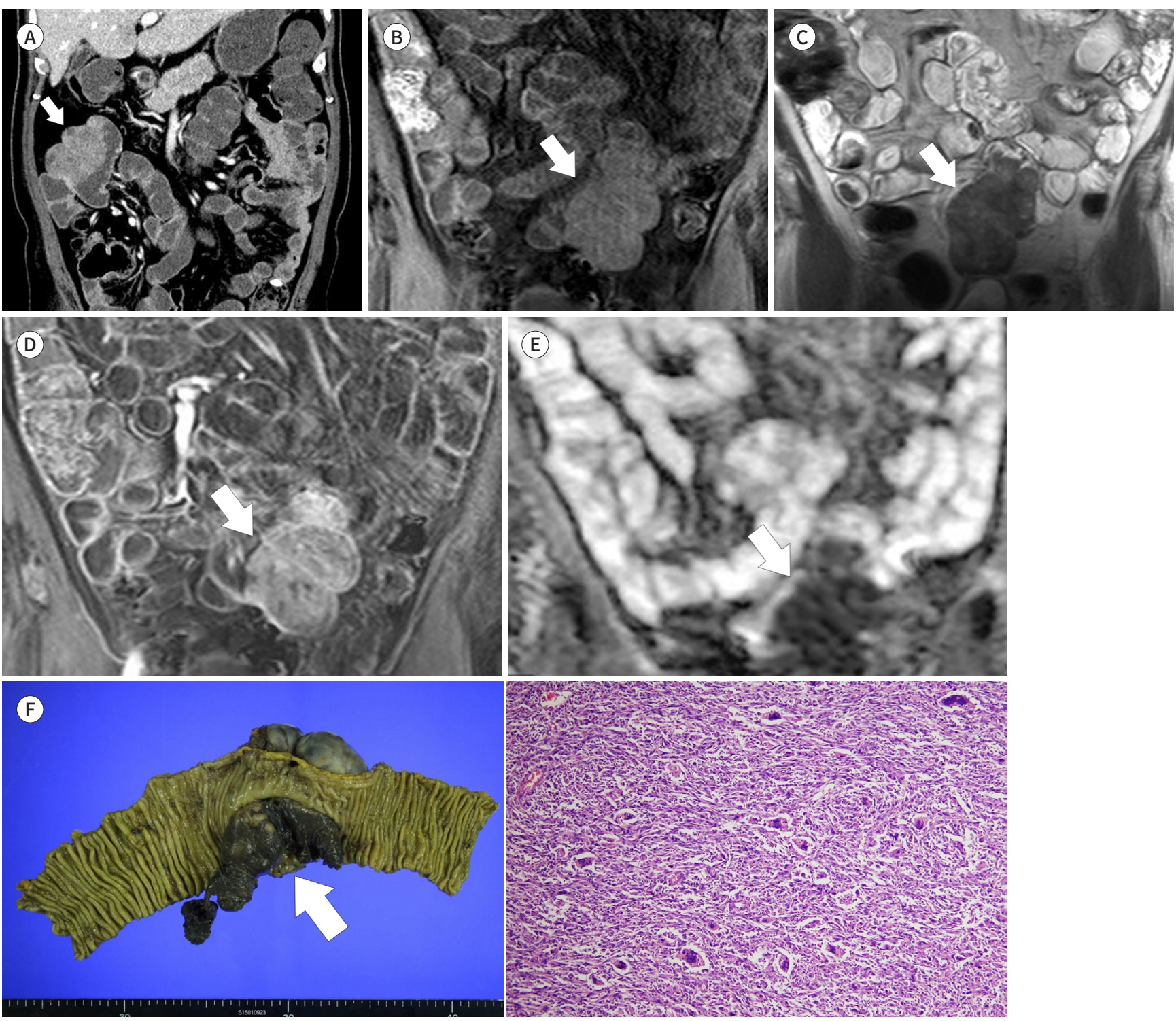
$\times 7.9 \times 3.8 \mathrm{~cm}$ exophytic soft mass was identified in the ileal wall (Fig. 1F). The mass passed though all layers, and the center of the mass was located in the subserosal layer. A dissected surface of the mass exhibited variegated appearance composed of whitish-gray, soft, fishflesh appearance with multifocal geographic hemorrhagic and necrotic foci. Microscopic examination revealed a relatively demarcated multilobulated tumor involving the mucosal to serosal layers. Necrotic and hemorrhagic change was observed, especially in the outer portion. The mass exhibited solid sheets of malignant tumor cells, which were a mixture of spindle cells arranged in a vague fascicular pattern, loosely cohesive epithelioid cells with abundant dense eosinophilic cytoplasm and eccentric nuclei, and pleomorphic cells. In addition, a considerable number of bizarre, multinucleated tumor giant cells were scattered (Fig. 1F). On immunohistochemistry, the tumor cells were negative for cytokeratin, smooth muscle actin, desmin, MyoD1, myogenin, c-kit, CD34, HMB45, Melan-A, and S-100 protein. The final diagnosis was UPS, Federation Nationale des Centres de Lutte le Cancer grade 3.

One week after surgery, the patient developed motor weakness and sensory impairment of the left upper extremity. Brain MRI revealed multiple enhancing nodules with hemorrhage and edema, suggesting brain metastasis. The patient died 3 months later due to clinical deterioration.

\section{DISCUSSION}

UPS is a heterogeneous group of soft tissue sarcomas that are known to occur in all parts of the body, but most commonly in the extremities. Despite its ubiquity, small bowel UPS is an extremely rare disease; consequently, few cases have been reported, with only 21 reported in the literature available in English to date. In our literature review, clinical symptoms and signs of small bowel UPS were nonspecific and included abdominal pain, vomiting, fever, weight loss, GI bleeding, and intussusception. In our patient, anemia found incidentally was the initial presentation, and the GI bleeding was suspected due to high stool hemoglobin levels.

Among the 21 previously reported cases, CT findings in primary small bowel UPS were described in 13 and were nonspecific (Table 1). The findings were usually described simply as 'small bowel tumor' or 'small bowel intussusception with suspicious tumor.' Karki et al. (1) analyzed 12 cases of primary ileal UPS. The authors described the characteristic findings of small bowel UPS, demonstrating that it was relatively smaller in size than UPS in other parts of the body. They also described its exophytic nature with intraluminal and intramural growth, which were characteristics similar to those noted our case. In addition, 4 cases of small bowel UPS were reported in Korean, and in two cases, aneurysmal dilatation of small bowel involved by UPS was noted (2). MRI was performed in 2 cases reported in the literature available in English (3, 4). Imaging findings were, however, described in only 1 case (4) as a pelvic mass, with $\mathrm{T} 1$ intermediate and $\mathrm{T} 2$ high SI without mention of an enhancement study.

To our knowledge, there have been no reports of small bowel UPS describing MR enterography findings. MRI of UPS in other organs reveals nonspecific features and a soft tissue mass. The mass usually has intermediate to low T1 SI, similar to adjacent muscles, and heterogeneously intermediate to high T2 SI; it also exhibits enhancing solid portions after intravenous contrast administration. If the tumor exhibits hemorrhage, calcification, necrosis, or 
Table 1. Previously Reported CT Findings of Small Bowel Undifferentiated Pleomorphic Sarcoma in the English Literature

\begin{tabular}{|c|c|c|c|c|c|}
\hline Author & $\begin{array}{c}\text { Year of } \\
\text { Publication }\end{array}$ & Sex & Age (Years) & Location & CT Findings \\
\hline Fukunaga et al. & 1999 & $\mathrm{~F}$ & 50 & lleum & $\begin{array}{l}\text { Distal small intestine in the pelvic cavity, colonic dilatation, and } \\
\text { ascites }\end{array}$ \\
\hline Farinon et al. & 1999 & $\mathrm{~F}$ & 61 & Duodenum & Infiltrating duodenal mass $(6 \mathrm{~cm})$ \\
\hline Umehara et al. & 2000 & M & 16 & Jejunum & Intussusception with small intestinal tumor \\
\hline Kobayashi et al. (4) & 2001 & M & 71 & Ileum & Oval mass $(8 \mathrm{~cm})$ with diffuse enhancement in the pelvis \\
\hline Kotan et al. & 2002 & M & 58 & Ileum & Intussusceptions of the small intestine with suspected tumor \\
\hline Jiao et al. & 2002 & M & 76 & Jejunum & Focal thickening of the wall of the small intestine \\
\hline Hasegawa et al. & 2004 & M & 52 & Ileum & Intussusception of the small intestine \\
\hline Wang et al. (9) & 2005 & M & 61 & Duodenum & Duodenal tumor \\
\hline Spanos et al. & 2005 & M & 41 & Jejunum & Intussusception of the jejunum \\
\hline Fu et al. & 2007 & M & 43 & Small intestine & Multiple intussusceptions of the small intestine \\
\hline Katsourakis et al. (10) & 2011 & $\mathrm{~F}$ & 67 & Jejunum & Tumor in the pelvic cavity near the small intestine \\
\hline Karki et al. (1) & 2012 & M & 79 & lleum & Intraluminal and intramural mass without necrosis in the ileum \\
\hline Giuliani (3) & 2013 & M & 67 & Vaters papilla & Mass in the pancreatic head and duodenum with enhancement \\
\hline
\end{tabular}

a myxoid portion, it may be heterogeneous (5). Our case also presented with a nonspecific soft tissue mass exhibiting heterogeneous intermediate T1 and T2 SI with heterogeneous enhancement, similar to UPS in other parts of the body. The diffusion restriction of the mass could be explained by its dense cellularity with pleomorphic cells. Multifocal punctate T2 high SI may represent necrotic portions, and non-enhancing portions on dynamic study suggest necrosis or hemorrhagic portions.

Our primary diagnosis was malignant GIST based on CT and MR enterography findings. Small bowel GIST often presents as an exophytic mass and may be accompanied by endoluminal or both exo- and endoluminal growth. GIST may exhibit internal hemorrhage or necrosis (6). The present case involved a large mass with both exo- and endoluminal growth with heterogeneous enhancement, and was difficult to diagnose as anything other than malignant GIST based on imaging findings and incidence. Other possible diagnoses include lymphoma or primary ileal adenocarcinoma.

The most common metastasis sites of malignant GIST are the liver and peritoneum. Extraabdominal metastasis of GIST is very uncommon (7). In the present case, brain metastasis developed rapidly, which may be an additional clue to differentiate small bowel malignant tumors from GIST. Kobayashi et al. (4) analyzed 25 cases (20 of which were reported in Japanese) of primary small bowel UPS, and its prognosis was very poor, with 1- and 2-year survival rates of $53.6 \%$ and $42.9 \%$, respectively. The prognosis of malignant GIST is better: 1-year relative (compared with the general United States population) survival rate 80\%; 5-year survival rate $45 \%$ (8).

We reported a case of small bowel UPS presenting as a large, polypoid, heterogeneously enhancing mass without obstruction or intussusception. The mass exhibited endo- and exoluminal growth patterns, internal necrosis and hemorrhage, and diffusion restriction. Because of its nonspecific imaging findings, small bowel UPS is usually diagnosed as GIST after imaging studies. Radiologists should be aware that UPS can occur in the GI tract, including 
the small bowel, and consider UPS in the differential diagnosis, especially when the mass mimics malignant GIST but exhibits more aggressive clinical features such as extra-abdominal metastasis.

\section{Conflicts of Interest}

The authors have no potential conflicts of interest to disclose.

\section{REFERENCES}

1. Karki B, Xu YK, Wu YK, Zhang WW. Primary malignant fibrous histiocytoma of the abdominal cavity: CT findings and pathological correlation. World J Radiol 2012;4:151-158

2. Kim YR, Lee YH, Yoon KH, Yun KJ. CT findings of primary undifferentiated pleomorphic sarcoma in the small bowel: a case report. J Korean Soc Radiol 2015;73:323-327

3. Giuliani J. Primary malignant fibrous histiocytoma of Vater' s Papilla: first reported case. J Gastrointest Cancer 2013;44:366-367

4. Kobayashi K, Narita H, Morimoto K, Hato M, Ito A, Sugiyama K. Primary malignant fibrous histiocytoma of the ileum: report of a case. Surg Today2001;31:727-731

5. Meyers SP. MRI of bone and soft tissue tumors and tumorlike lesions: differential diagnosis and atlas. Stuttgart and New York: Thieme 2008

6. Amzallag-Bellenger E, Oudjit A, Ruiz A, Cadiot G, Soyer PA, Hoeffel CC. Effectiveness of MR enterography for the assessment of small-bowel diseases beyond Crohn disease. Radiographics 2012;32:1423-1444

7. Kroep JR, Bovée JV, van der Molen AJ, Hogendoorn PC, Gelderblom H. Extra-abdominal subcutaneous metastasis of a gastrointestinal stromal tumor: report of a case and a review of the literature. $J$ Cutan Pathol 2009;36:565-569

8. Tran T, Davila JA, El-Serag HB. The epidemiology of malignant gastrointestinal stromal tumors: an analysis of 1458 cases from 1992 to 2000. Am J Gastroenterol 2005;100:162-168

9. Wang ZS, Xiong CL, Zhan N, Xiong GS, Li H, Hu H. Primary malignant fibrous histiocytoma of the small bowel: a report of an additional case in duodenum. Int J Gastrointest Cancer 2005:36:105-112

10. Katsourakis A, Noussios G, Hadjis I, Evangelou N, Chatzitheoklitos E. Primary malignant fibrous histiocytoma: a rare case. Case Rep Med 2011;2011:134801 
소장의 원발성 미분화성 다형성육종 증례 보고: 전산화단층촬영 및 $\mathrm{MR}$ 소장조영술에서의 영상 소견

한예은 ${ }^{1}$ 채수영 ${ }^{1} \cdot$ 이정현 ${ }^{2} \cdot$ 박범진 ${ }^{1} \cdot$ 성득제 ${ }^{1}$ 한나연 ${ }^{1}$ 심기춘 ${ }^{1} \cdot$ 김민주 $^{*}$

소화기관에서 발생한 미분화성 다형성육종은 매우 드문 종양이며, 지금까지 영문 문헌상 21 개의 소장의 원발성 미분화성 다형성육종 증례만이 보고되었다. 전산화단층촬영 소견은 매 우 비특이적이며 자기공명영상 소견은 한 증례만 보고되어 영상의학적 소견이 잘 알려져 있 지 않다. 우리는 72세 남성에서 생긴 회장의 원발성 미분화성 다형성육종의 전산화단층촬영 과 자기공명영상을 이용한 소장조영술을 시행하였으며, 소장 폐색을 동반하지 않은 비균일 한 조영증강을 보이는 소장 종괴로 보였다. 일반적으로 악성 위장관기질종양으로 오인되나 미분화성 다형성육종의 경우, 예후가 더 나쁘고 복강 외 전이의 발생률이 높은 임상경과를 보여 감별 질환을 요한다.

고려대학교 의과대학 안암병원 ${ }^{1}$ 영상의학과, ${ }^{2}$ 병리과 